\title{
Dynamics of Trafficking in Human Beings and the Role of the Social Worker (Albanian Case)
}

\author{
Muco Ervin, (PhD candidate) \\ University of Tirana, Albania
}

Doi: 10.19044/esj.2017.v13n32p89 URL:http://dx.doi.org/10.19044/esj.2017.v13n32p89

\begin{abstract}
The phenomena of Human Trafficking constitutes a violation of human rights, by restricting the freedom and putting in danger the lives of individuals, communities, and states. It positions individuals on slavery conditions and as a consequence victimizes them. Meanwhile, profits generated by human trafficking, the low risk and cost of engaging in this criminal activity, makes it very attractive for individuals, criminals networks, and the state as well.

This causes negative consequences not only on individuals live but also on the economy and the political stability of a country. It harms social relation, brings a sense of fear and unsafety, and decreases the social trust among members of the community and state institutions. Moreover, THB has a negative impact on the economy by enabling individuals, organized crime, corporates, and states to maximise their profits by exploiting people. To succeed in the fight against THB and the reintegration process as well, we must recognize the factors that motivate and support it and actors involved in this operations (individuals, groups, organizations, and institutions). In this context, the role of the social worker is critical to understanding the phenomena and its consequences at different levels: micro, mezzo, and macro.
\end{abstract}

Keywords: Social worker, THB, reintegration

\section{Methodology}

This article analyses available information and data on THB. It includes the number of people trafficked, globally and locally (in Albania), services provided to them, challenges faced by the state and other stakeholders in the fight against the phenomena and the reintegration process. Given the complexity of the phenomena, this article aims to identify the state's responsibility about THB. The state has an ambiguous nature. On one side is engaged in the fight against THB, and on the other side it can sponsor, support or create the incentives for the phenomena to happen. 
In this article, a various approaches are used including: social work perspective, criminology, and human rights.

Social work has built up its identity in dealing with social problems. Its purpose is to generate new knowledge about causes, consequences and possible solutions to various problems that concern individuals, groups, and societies at local or global levels. Working at different levels (individual, mezzo, and macro) and heterogeneous environments, social workers, are in a favorable position to accomplish this mission. There is also a broad agreement on the fact that social work is engaged in human rights and justice and that it exists to help, support and train those who suffer from the adverse effects of social inequalities. Social work has the function of social integration. At the same time, it deals with failures, in specific areas, of policies such as crime, health, and education. ${ }^{2}$

To social workers, the knowledge and criminologists' perspective on trafficking is of great importance. At the same time, the recognition of domestic and international laws constitute the terrain where social workers exercise their activity in providing services for VHT.

Moreover, when studying THB social workers must focus on aspects of the crime that are not criminalized, rather than those already criminalized. This approach would be similar to what Michalowski calls a zemiologist view, but with some changes. First, he thinks that crime defined by law should not cease to be a meaningful category for criminological research. Nonetheless, state-prohibited crimes and state-controlled mechanisms for its control should be reconstructed from being certain structures, for defining the subject of criminological research, into the problematic consequences of large-scale patterns of social relations and social structures which form, at the same time the production of the social problem and our understanding of dealing with it. ${ }^{3}$

\section{Methods}

The present article is based on secondary sources: books, scientific articles, national and international reports, annual reports as well as government reports.

\section{Introduction}

THB is a market where victims get considered as commodities that could be bought, sold, traded and used. Worldwide there has been and still has demand for sexual services and free labor work. This demand is increasing by the improvement of live quality and wealth in developed countries.

${ }^{2}$ Prof. Asquith S, Dr. Clark, C. \& Prof. Waterhouse L. The Role of the Social Worker in the 21 st Century - A Literature Review. The University of Edinburgh. Pg. 2

${ }^{3}$ Michalowski, J, R. What is Crime? Published online: 18 November 2015. Springer Science+Business Media Dordrecht 2015. Pg. 194 
Aforementioned is more often in the areas where there is no need for a qualification such as agriculture, households, building, and construction.

The development of sex industry is sustained by men who buy sexual services supplied by women and children. The sex industry has been enlarged from traditional brothels and street prostitution to escort services, "sex clubs," massage parlors and residences. ${ }^{4}$

The opportunities are generated by people ready to migrate from source countries and the demand for such services in destination countries. In cases of internal trafficking, migration, often happens from rural areas towards the urban areas with higher life quality and wealth. The need for economic safety and the desire to improve the quality of life are among the factors that enable the increase of the number of VHT.

Same as the legal businesses, THB is led by profit. Criminals are looking for new markets trying to adapt to the environment they work and exploiting the existing labor workforce. The criminal enterprises engaged in THB are not uniform, and they operate in different cultural and political contexts.

Despite other criminal activities such as trafficking of drugs, THB might operate in legal markets such as agriculture, construction, households, transport, and other industries. That will be the reason why we should examine THB and exploitation within the context of economic activity and focus on economic conditions (including market opportunities and legislation) that lead the business in general, and illegal business (THB) in particular. ${ }^{5}$

\section{Definitions}

\section{For this study the following definitions will be used: Trafficking in Person}

The Article 3, paragraph (a) of the Protocol to Prevent, Suppress and Punish Trafficking in Persons defines Trafficking in Persons as: the recruitment, transportation, transfer, harbouring or receipt of persons, by means of the threat or use of force or other forms of coercion, of abduction, of fraud, of deception, of the abuse of power or of a position of vulnerability or of the giving or receiving of payments or benefits to achieve the consent of a person having control over another person, for the purpose of exploitation. Exploitation shall include, at a minimum, the exploitation of the prostitution

\footnotetext{
4 Aronowitz A, Theuermann G. and Tyurykanova E. Analysing the Business Model of Trafficking in Human Beings to Better Prevent Crime. OSCE, May 2010. Pg. 23

${ }^{5}$ Profits and poverty: the economics of forced labor. ILO, 2012
} 
of others or other forms of sexual exploitation, forced labor or services, slavery or practices similar to slavery, servitude or the removal of organs. ${ }^{6}$

\section{Slavery}

Slavery will be defined according to 'Bellagio-Harvard Guidelines on the Legal Parameters of Slavery.'

The Legal definition is found in Guideline 1: The legal definition of slavery in international law is found in Article 1(1) of the 1926 Slavery Convention, which reads: 'Slavery is the status or condition of a person over whom any or all of the powers attaching to the right of ownership are exercised.'

There should be a distinction between Slavery and Forced Labour. According to the 'Guideline 8': ... forced labor will only amount to slavery when, in substance, there is the exercise of the powers attaching to the right of ownership. Slavery will not be present in cases of forced labor where the control over a person tantamount to possession is not present. ${ }^{7}$

\section{Estimations of number of trafficked people}

According to Global Index on Slavery 2016, there are around 45.8 million slaves globally. Of these, $58 \%$ live in India, China, Pakistan, Bangladesh, and Uzbekistan. ${ }^{8}$ Meanwhile, in Europe, there are approximately $1,243,400$ slaves. ${ }^{9}$ However, in many of the European countries, more than $90 \%$ of slavery is unidentified in official data. Most of those unknown victims consist of people stacked in forced labor such as slavery out of the sex industry, agriculture, manufactures, mining, households, building and construction, tourism and hospitality and other sectors as well). ${ }^{10}$ Referring to the report in Albania there are around 8600 slaves. $^{11}$

Based on above estimates the 'slaves population is much bigger than the population of Australia and more than seven times higher than that of Ireland.' That is, generally, a hidden population. Decades ago, when slavery used to be legal in many countries, slaves were counted and measured,

\footnotetext{
${ }^{6}$ Protocol to Prevent, Suppress and Punish Trafficking in Persons, Especially Women and Children, Supplementing the United Nations Convention Against Transnational Organized Crime.

${ }^{7}$ http://www.law.qub.ac.uk/schools/SchoolofLaw/FileStore/Filetoupload,651854,en.pdf

${ }^{8}$ The Global Slavery Index 2016. Pg. 4

${ }^{9}$ Ibid. Pg. 58

${ }^{10}$ Directorate-General for External Policies of the Union, Addressing Contemporary Forms ofSlaveryinEU External Policy. Pg. 4

${ }^{11}$ The Global Slavery Index 2016. Pg. 28
} 
their economic value was registered, and they were listed in legal documents from contracts to heredity. ${ }^{12}$

At the same time, on a global scale, countries with the more significant number of slavery compared to their population are North Korea, Uzbekistan, Cambogia, India, and Qatar. In North Korea, there are estimations that the sanction of forced labor imposed by government happens in a prison system in the form of the labor camp. The North Korean women are subjects of forced labor and commercial sex in China and neighbor countries. The Uzbekistani government continues to subject its citizens on forced labor on an annual harvest of cotton.

Countries with the highest absolute number of modern slavery are India, China, Pakistan, Bangladesh, and Uzbekistan. Some of this countries ensure low-cost work to produce goods designed for markets in Western Europe, Japan, North America and Australia. States with the lowest prevalence of modern slavery, compared to their population are Luxemburg, Ireland, Norway, Denmark, Swiss, Austria, Sweden, Belgium, United States, Canada, Australia and New Zealand. These countries, have a higher level of economic wealth, government reaction, low levels of conflict and political stability and the will to fight slavery. ${ }^{13}$

Referring to Global Slavery Index 2016, Albania is ranked 37 out of 167 States, belonging to "BB" group. ${ }^{14}$ According to the report, this group has the following characteristics:

The government has introduced a response to modern slavery, which includes short-term victim support services, a criminal justice framework that criminalizes some forms of modern slavery, a body to coordinate the response, and protection for those vulnerable to modern slavery. There may be evidence that some government policies and practices may criminalize and cause victims to be deported and facilitate slavery. ${ }^{15}$

According to ILO around 20.9 million of people are victims of forced labor globally, "stacked" in work or deceived and from which they cannot escape. In some countries, forced labor, established by the state, is a significant problem and continuous vigilance is needed to protect labors freedom from this exploiting and repressive practices. ${ }^{16}$

The higher portion of labors exploited in economic activities and mostly those in forced labor imposed by the State did not move from their regions. There are approximately 9.2 million of victims (44\% of the total sum)

${ }^{12}$ Directorate-General for External Policies of the Union, Addressing Contemporary Forms of Slavery in EU External Policy. Pg. 8

${ }^{13} \mathrm{https} / / / \mathrm{www}$. globalslaveryindex.org/findings/

${ }^{14} \mathrm{https}: / / \mathrm{www}$. globalslaveryindex.org/index/

${ }^{15} \mathrm{https} / / / \mathrm{www}$.globalslaveryindex.org/methodology/

${ }^{16}$ Profits and poverty: the economics of forced labor. ILO. 2012. Pg. 11 
that moved within and out of their countries. Meanwhile, $11.8 \%$ has been the subject of forced labor in their own countries of origin or residence. This data shows that the movement could be an essential factor of vulnerability for specific labor groups but, not for others. ${ }^{17}$

Of the total of 20.9 million of forced labour, 18.7 million $(90 \%)$ is exploited in private economy, by individuals or enterprises; 4.5 million (22\%) are victims of sexual exploitation and 14.2 million $(68 \%)$ are victims of forced labour in economic activities such as: agriculture, construction, households or manufactures. The rest of 2.2 million (10\%) are engaged in forced labor imposed by the state such as prisons, or in works imposed by state's military or rebel armed forces. ${ }^{18}$

\section{Profits of THB}

The data show that 3 in every 1000 people work in forced labor globally. Women and girls represent the most significant share of this sum with more than 11.4 million (55\%), compared to 9.5 million $(45 \%)$ men and boys. Meanwhile, $74 \%$ (15.4 million) of victims belong to the group age 18 years old and above; children 17 years old and below represent $26 \%$ of the total (or 5.5 million victims of THB).

In 2005 ILO estimated that the global profits coming from forced labor were at least US\$44 billion per year. Today, ILO estimates that the total of profits generated by forced labor in private economy (without considering the exploitation by the State) is US\$150 billion per year, globally. ${ }^{19}$

The yearly profits are higher in developed countries (US\$34,800 per capita), followed by Middle East (US\$15,000 per capita) and the lowest in Asia-Pacific (US\$5,000 per capita) and Africa (US\$3,900 per capita).

The profits generated by sexual exploitation cover the highest level of profits. That might be explained by the demand for such services with affordable prices and low-cost investment capital followed with this activity. With a median globally profit of US\$ 21,800 per year, this sector is six times more profitable than any other form of forced labor and five times more profitable than exploitation and forced labor in household services. ${ }^{20}$ In a global scale, 2/3 of profits coming from forced labor belong to forced sexual exploitation, reaching a total of US\$99 billion per year. ${ }^{21}$

Studies have shown that prostitution can result in profits of investments varying from 100-1000 percent; at the same time, even the sectors

\footnotetext{
${ }^{17}$ Profits and poverty: the economics of forced labor. ILO. 2012 Pg. 15

${ }^{18}$ Profits and poverty: the economics of forced labor. ILO. 2014. Pg. 7

${ }^{19}$ Ibid. Pg. 45

${ }^{20}$ Profits and poverty: The economics of forced labor. ILO. 2014. Pg. 14-15

${ }^{21}$ Ibid. Pg. 27
} 
with a lower profit rate such as agriculture might generate above the $50 \%$ of the profit. $^{22}$

Victims exploited on forced labor, including households, agriculture, and other economic activities generate annual profits of around US\$51 billion. Of them, profits coming from forced labor in agriculture, including forestry and fishing, are estimated to be around US\$9 billion per year. Benefits coming from other economic activities are expected to be approximately US\$34 billion per year, including construction, manufacture, mining, and services. Lastly, it is estimated that domestic economies that employ local labors in forced labor conditions save roughly US\$8 billion per year by not paying or paying for less their labors. ${ }^{23}$

\section{Identification of VHT and criminals' punishment}

Regardless of the number, relatively high, of trafficked people ( 45.8 million people) the process of identification of victims and the punishment of the perpetrators is still at low levels. ${ }^{24}$

During the period 2007-2010, there were 460 trafficking routes identified. Despite this, the criminal prosecution and punishment of criminals and the fight against criminal groups remained low. Data offered by the US Department of State on Trafficking in Person, show that criminal prosecution and punishment of the authors, as well as the identification of victims, had their up and downs on years. For instance, the number of criminal prosecution in 2003 was 7,992, and in eight consecutive years, it decreased significantly. It was only on 2011 that it reached the approximate number of those of 2003, representing 7,909. From 2013-2015 there is an increase of criminal prosecution cases experiencing a growth of almost $50 \%$.

The situation is similar regarding the punishment of perpetrators of THB. The data show that there is not a consistency and significant increase of these cases. Statistics show that two most significant periods with the highest number of punishment belong to the year 2009 with 4,166 cases and 2015 with 6,609 cases. Referring to the Global Report on Trafficking in Person 2012 of 132 states covered by this report, $16 \%$ did not record a single punishment between 2007 and $2010 .^{25}$

The data on VHT show that the number of identified victims experienced a significant increase of $42.5 \%$ from 2010 to 2015. Despite the claim of the US Department Report, that fight against THB has undergone

\footnotetext{
22 Aronowitz A, Theuermann G. the Tyurykanova E. Analysing the Business Model of Trafficking in Human Beings to Better Prevent Crime. OSCE, May 2010. Pg. 25-26

${ }^{23}$ Ibid. Pg. 15

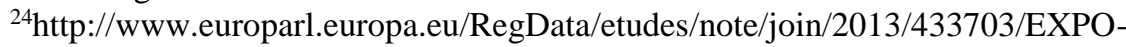
DROI_NT(2013)433703_EN.pdf

${ }^{25}$ Global Report on Trafficking in Persons 2012
} 
considerable improvement the data show that this effort remains inferior compared to the number of people trafficked globally.

Table 1: Data on THB including some criminal prosecution, number of criminals punished, victims identified and new laws or amended. Data on bracket show the number of cases/victims of forced labor. ${ }^{26}$

\begin{tabular}{|c|c|c|c|c|}
\hline Year & $\begin{array}{c}\text { Criminal } \\
\text { Prosecution }\end{array}$ & $\begin{array}{c}\text { Punishment of } \\
\text { Criminals }\end{array}$ & Victims Identified & $\begin{array}{c}\text { New laws or } \\
\text { Amended }\end{array}$ \\
\hline 2003 & 7,992 & 2,815 & - & 24 \\
\hline 2004 & 6,885 & 3,025 & - & 39 \\
\hline 2005 & 6,178 & 4,379 & - & 40 \\
\hline 2006 & 5,808 & 3,160 & - & 21 \\
\hline 2007 & $5,682(490)$ & $3,427(326)$ & - & 28 \\
\hline 2008 & $5,212(312)$ & $2,983(104)$ & 30,961 & 26 \\
\hline 2009 & $5,606(432)$ & $4,166(335)$ & 49,105 & 33 \\
\hline 2010 & $6,017(607)$ & $3,619(237)$ & 33,113 & 17 \\
\hline 2011 & $7,909(456)$ & $3,969(278)$ & $42,291(15,205)$ & 15 \\
\hline 2012 & $7,705(1,153)$ & $4,746(518)$ & $46,570(17,368)$ & 21 \\
\hline 2013 & $9,460(1,199)$ & $5,776(470)$ & $44,758(10,603)$ & 58 \\
\hline 2014 & $10,051(418)$ & $4,443(216)$ & $44,462(11,438)$ & 20 \\
\hline 2015 & $18,930(857)$ & $6,609(456)$ & $77,823(14,262)$ & 30 \\
\hline Total & $103,435(5,924)$ & $53,117(2,940)$ & $369,083(68,876)$ & 372 \\
\hline
\end{tabular}

\section{Dimensions of THB in Albania}

The research work regarding the THB in Albania faces many issues, but among them, the identification of an approximate number remains a challenge. The data offered in Global Report of Trafficking in Person from 2001-2017 show that Albania has been and continued to be an origin, transit and destination country for VHT. Moreover, there seems to be a gap in data for the first decade after the collapse of communism in 1990. Data from different sources show that approximately 120,000 victims or more have been trafficked every year from Balkan to the European Union. During 1990, Albanian and Moldavian women, the poorest in Europe, have been among most trafficked groups. ${ }^{27}$ Moreover, is claimed that only in Western Europe

${ }^{26}$ Data generated by US Department, Global Report on Trafficking in Person for the referential years.

${ }^{27}$ United Nations Office on Drugs and Crime. Crime and its Impact on the Balkans and Affected Countries. March 2008 
there have been more than 30000 Albanian prostitutes. $^{28}$ Meanwhile, according to the state police, the number of victims exploited for prostitution has been $5000 .{ }^{29}$ According to Kara during 1990, Albania has been the leading transit country for slave's trade from Eastern Europe toward Italy and from Italy to the rest of Western Europe. ${ }^{30}$ Most of them used to be victims of sexual exploitation, representing $100 \%$ of victims in $2000,88.1 \%$ in $2001,91.2 \%$ in $2002,85.2 \%$ in 2003 and $79.8 \%$ in $2004 .^{31}$

During 2015 the Albanian government and NGOs identified 109 VHT and potential trafficking victims. ${ }^{32}$

\section{Understanding states crime}

Chambliss (1989) defined the concept of state's organized crime as a 'crime defined by law as such (criminal)' and described it as 'acts defined by the law as criminal and committed by state officials in the course of their work as state's representatives.' Aware of the restriction of its first definition, Chambliss reviewed the definition by suggesting that the analysis of State Crime should include 'behavior that violates international agreements and reinforced principles in the courts and treaties of international institutions. ${ }^{33}$

According to Kramer C. and R. Michailowski "state crime is any action that violates public international law, international criminal law, or domestic law when these actions are committed by individuals acting in official or covert capacity as agents of the state pursuant to expressed or implied orders of the state, or resulting from state failure to exercise due diligence over the actions of its agents. ${ }^{34}$

According to Watts: 'State crimes include those cases where states have been intentionally involved in policies and crime (murderer), systematic terrorism, intentional dissolution of families (including kidnapping), systematic arrest, threat and surveillance of its citizens. Much of this activity

${ }^{28}$ Sokoli L \& Gëdeshi I. Trafikimi Rasti i Shqipërisë. Institute i Sociologjisë, 2006, Tiranë. Pg. 9

${ }^{29}$ Ibid. Pg. 8

${ }^{30}$ Kara. S. Columbia University Press. New York. Sex trafficking. Inside the Business of Modern Slavery. Pg. 134

${ }^{31} \mathrm{http}: / / \mathrm{ww}$.legislationline.org/documents/id/7645

${ }^{32}$ US Department of State Report on Trafficking in Person. June 2016. Pg 71.

${ }^{33}$ ' http://www.politicaanticrimen.com/sites/all/themes/bluemasters/pdfs/BJC_rjm.pdf

${ }^{34}$ Kramer C. R and Michalowski J. R. War, Aggression, and State Crime: A Criminological Analysis of the Invasion and Occupation of Iraq. Revised for the British Journal of Criminology, October 2004. Pg. 5 
has been the product of formal political processes - some of them altered and secretive, many of them not.' 35

Consequently, many of this activity is invisible for the fact that it has never been labeled as 'crime.' It is a consequence of political and conceptual problems that accompany every effort to talk about state crimes. ${ }^{36}$ In this way, Watts gives us a significant understanding of state crime. Each policy aims to gain legitimacy before its implementation.

Green and Ward (2000) have argued that definition of the state crime that relies primarily on a legalistic framework is too narrow in scope. As an alternative, they define state crime as the area of overlap between two distinct phenomena: (1) violation of human rights and (2) state organizational deviance that would be subject to widespread censure if it were known. ${ }^{37}$

\section{States responsibility on THB phenomena}

The State's responsibility regarding the fight against the phenomenon of THB and the process of reintegration of victims derives from its obligation to guarantee the rights and freedoms of the individual. The state has the responsibility of recognizing the phenomenon, drafting the relevant legislation, setting up the structures and institutions responsible for their implementation, and building partnerships with different actors at national or international level. In this context, the "3P" paradigm-prosecution, protection, and prevention - continues to serve as the fundamental framework used around the world to combat human trafficking.

Prosecution. To be successful in fighting human trafficking governments must ensure an effective law enforcement action.

Protection constitutes one of the essential a spects of the victimcentered approach that the international community takes in their efforts to eradicate modern slavery. Effective victim protection aims the identification of the victims, referrals to a comprehensive array of services, and supporting victims to rebuild their lives.

Prevention aims to address the tactics of human traffickers head on. Strategic intervention programs can reach at-risk populations before they experience deceitful recruitment practices. Meaningful partnerships between public and private sectors and civil society to expand awareness, leverage expertise, and facilitate creative solutions. Prevention efforts should also encapsulate cross-cutting endeavors, such as amending labor laws; robustly enforcing labor laws; implementing measures, such as birth registration, that

35 Watts, R, Bessant, J \& Hil, R 2008, International criminology: a critical introduction, Routledge, Abingdon, UK; New York. Pg. 214

${ }^{36}$ Ibid, pg. 209

${ }^{37}$ Ronald C. Kramer and Raymond J. Michalowski. War, Aggression and State Crime. BRIT.

J. Criminol. (2005).Fq. 446-448 
reduce vulnerabilities to trafficking; developing and monitoring labor recruitment programs; strengthening partnerships among law enforcement, government, and NGOs; emphasizing effective policy implementation with stronger enforcement, better reporting, and government-endorsed business standards; monitoring supply chains to address forced labor, including through government procurement policies; and working to reduce demand for commercial sex. Additionally, recent innovations in private sector engagement on trafficking in persons hold potential to advance prevention efforts. A new push for corporate accountability calls on companies to focus additional attention on their supply chains, specifically to assess the recruitment of their workforce and that of their suppliers, including those harvesting, collecting, or mining raw materials.

Also, a "fourth $\mathrm{P}$ "—for partnership_serves as a complementary means to achieve progress across the 3Ps and ensure all segments of society are enlisted in the fight against modern slavery. ${ }^{38}$

\section{Understanding the role of the social workers in thb}

The profession of the social worker is based on respect for the dignity and value of all people. It promotes individual rights, self-determination, and participation in society. Social workers challenge discrimination, recognize diversity, and work to overcome social exclusion. They support those who are affected by poverty, disadvantage, and social exclusion. ${ }^{39}$

Social workers are engaged in:

- $\quad$ Research work. They generate new perspectives to understand the factors causing and supporting THB and actors involved in this process. They also identify the barriers in the fight against this phenomenon and the reintegration process;

- $\quad$ Providing services for VHT such as identification of the victims or counselling; and

- $\quad$ Policymaking process and lobbying or advocating for victims rights.

\section{Understanding micro, mezzo and macro levels in social work}

- $\quad$ The practice of social workers with clients is often divided into three different levels: micro, mezzo, and macro.

- Micro-social work practice is the most common practice and happens directly with an individual client or family to deal with their problems. It includes: helping individuals to find appropriate housing, health care, and social services; family therapy and individual counseling; treatment of people suffering from a mental health condition or substance abuse problem. Micro-

\footnotetext{
${ }^{38} \mathrm{https}: / /$ www.state.gov/documents/organization/272970.pdf

${ }^{39}$ Prof. Asquith S, Dr. Clark, C. \& Prof. Waterhouse L. The Role of the Social Worker in the 21 st Century - A Literature Review. The University of Edinburgh. Pg. 2
} 
practice used too in the military, where the social worker aims to help the military members to deal with the challenges following the military life and accessing the benefits entitled to them by their service.

- Mezzo social work practice happens on an intermediate scale, involving neighborhoods, institutions or other smaller groups.

- Macro-level social work practice is interventions provided on a large scale that affects entire communities and systems of care. Examples include lobbying to change a law, organizing a state-wide activist group or advocating for large-scale social policy change. Macro social work practice empowers clients by involving them in systemic change. ${ }^{40}$

\section{The perspective of ecosystems}

The ecological approach is a comprehensive theoretical base for effective social treatment. It provides strategies that enable the social worker to move from a micro level of intervention to a macro level of social treatment. It enables the social worker to impact a client system through policy and planning activities and psychotherapy or other micro-level approaches. Such a framework accords due to the recognition of the transactional relationship between environmental and human condition. This perspective allows the practitioner to efficiently treat problems and needs of various systemic levels including the individual, family, the small group, and the broader community. ${ }^{41}$

Theoretically, a trafficked person needs at least three critical environmental interactions to benefit a balanced perspective for a healthy development: Individual needs must be balanced by environmental resources; - Environmental opportunities should balance individual desires and aspirations; and

- $\quad$ Environmental requirements should balan

- $\quad$ ce individual skills and abilities. ${ }^{42}$

The client's ecosystem is composed of numerous overlapping systems including the family, the workplace, and the community, as well as other critical subsystems unique to each client. By using the concept of the transaction, this perspective suggests that there is a bidirectional and cyclic relationship between the client and the environment. It means that the problems of clients are not a result of individual pathology, but rather a product of a malfunctioning ecosystem. Thus problems in social functioning

\footnotetext{
${ }^{40} \mathrm{https}$ ://socialworklicensemap.com/macro-mezzo-and-micro-social-work/

${ }^{41}$ Pardeck, John T. (1988) "An Ecological Approach to Social Work Practice," The Journal of Sociology \& Social Welfare: Vol. 15: Iss. 2, Article 11. Pg. 133-134

${ }^{42}$ Gjermeni. E., Taga. I, Tahsini. I \& M. Meshi. Tiranë 2008. Mediaprint. Doracak i ofruesve të shërbimeve për mbrojtjen e viktimave të trafikimit, pg. 53
} 
are viewed as interactive, reciprocal, and a dynamic set of forces operating between the client and the ecosystem. ${ }^{43}$

The ecological model strongly emphasizes the social functioning rather than mental malfunction. It suggests three main tasks for evaluation and intervention:

- Needs assessment (past and present) - in the context of existing resources;

- $\quad$ Assessment of personal aspirations (past and present) - in the context of existing opportunities; and

- $\quad$ Assessing your current personal skills - in the context of personal or social expectations for change. ${ }^{44}$

The ecological perspective offers a tremendous shift in thinking when viewing the process of assessment and treatment. The shift is away from the individual as the core focus of intervention to a perspective defined as the individual-in-the-ecology. The practitioner must conceptualize treatment as a strategy that involves working with individuals, families, small groups, and more extensive social systems to create change that promotes the best possible transactions between people and their environments. ${ }^{45}$

According to the US Department Report on Trafficking in Person 2015: Governments that embrace a victim-centered approach have adopted the following promising practices in witness protection:

\section{Care}

- Opportunities for victims to consider their options and make an informed decision about participating in criminal proceedings;

- Access to legal counsel for victims who wish to participate in the investigation and prosecution of their traffickers;

- Permitting a professional, such as a social worker, legal advocate, or counselor, to accompany and support victims throughout investigations and prosecutions;

- $\quad$ Collaborating with civil society and NGOs to ensure victims receive comprehensive support services, including mental health care, if requested;

- $\quad$ Offering victims placement in non-restrictive shelters that provide care appropriate to age, gender, and special needs;

- $\quad$ Helping victims secure safe, long-term accommodation; and

\footnotetext{
${ }^{43}$ Pardeck, John T. (1988) "An Ecological Approach to Social Work Practice," The Journal of Sociology \& Social Welfare: Vol. 15: Iss. 2, Article 11. Pg. 136-138

${ }^{44}$ Gjermeni. E., Taga. I, Tahsini. I \& M. Meshi. Tiranë 2008. Mediaprint. Doracak i ofruesve të shërbimeve për mbrojtjen e viktimave të trafikimit, pg. 53

${ }^{45}$ Pardeck, John T. (1988) "An Ecological Approach to Social Work Practice," The Journal of Sociology \& Social Welfare: Vol. 15: Iss. 2, Article 11. Pg. 138-139
} 
- $\quad$ Conducting safety planning and extend protection to victims' relatives, if necessary.

\section{Confidentiality}

- $\quad$ Protecting victims' identities and privacy;

- Allowing victims to provide testimony in a manner that is less threatening, such as testimonies that are written or recorded, delivered via video conference, or produced with audio or visual distortion; and

- $\quad$ Providing a separate waiting area for victims, for example in court, to minimize interaction with the accused traffickers or their associates.

\section{Communication}

- $\quad$ Explaining to victims how their testimony will be delivered and to what extent their identity will be revealed, if at all, to the defendant and the public;

- $\quad$ Establishing a point person to communicate in a language the victim understands and provide updates on the status of the case and information about available services; and

Informing and prepare victims on what to expect before testimony and court examinations, including realistic expectations in the sentencing phase. ${ }^{46}$

Allen-Meares and Lane (1987) in a recent article neatly summarize the core characteristics of the ecological approach to practice as follows:

1. The environment is a complex environment-behavior-person whole, consisting of a continuous, interlocking process of relationships, not arbitrary dualism;

2. The mutual interdependence among person, behavior, and environment is emphasized;

3. Systems concepts are used to analyze the complex interrelationship with the ecological whole;

4. Behavior is recognized to be site specific;

5. Assessment and evaluation should be through the naturalistic, direct observation of the intact, undisturbed, natural organism environment system. Journal of Sociology \& Social Welfare;

6. The relationship of the parts within the ecosystem is considered to be orderly, structured, lawful, and deterministic;

7. Behavior results from mediated transactions between the person and the multivariate environment;

${ }^{46}$ US Department of State. Trafficking in Persons Report, July 2015. Fq. 24-26 
8. The central task of behavioral science is to develop taxonomies of environments, behaviors, and behavior-environment linkages and to determine their distribution in the natural world. ${ }^{47}$

Furthermore, Max Siporin (1980) concludes that the ecological approach appears to be an extremely appropriate strategy for practice given the current context of social work practice. Siporin suggests that the ecological perspective contributes to social work practice through the following points:

1. A dynamic wholistic approach is stressed emphasizing the person and the sociocultural systems surrounding the person;

2. A strategy is offered through allowing the social worker to think regarding parts and wholes;

3. It encourages an edectical approach to practice;

4. It allows one to move to both micro and macro levels of assessment and intervention when working with a client system;

5. It stresses treatment planning and allows the practitioner to work at altering intersystemic relationships;

6. Given its multifactorial nature, the practitioner can develop and utilize a strong and varied repertoire of assessment and social treatment strategies. The ecological approach provides a balance between the person and the environment. This balance is critical to social work treatment and facilitates practice effectiveness and accountability. ${ }^{48}$

\section{Interventional methods of social work}

By having an open approach social work is not limited to its intervention and at the same time, it has access and relation with other parties engaged in the fight against THB and reintegration process. This can be seen as an enormous advantage because social workers get an insight on the situation and social problems of VHT in general, but also an understanding of the demand and supply side, such as the demand for sexual services and the providing of this services. At this point it must be mentioned, that social work intervention and support is provided to the clients, despite their legal status.

Moreover, social workers follow an "acceptance approach." Itmeans that the client situation will be accepted as the client introduces it to the social worker and they will not be judged on this.

Approaches used by social workers in their work with VHT include: "intervention in crises, psychological support, assistance with state authorities, assistance finding the appropriate accommodation, accompanying in the judicial processes, counseling services for the returnees, information and training, information and counseling for family members."

${ }^{47}$ Pardeck, John T. (1988) "An Ecological Approach to Social Work Practice," The Journal of Sociology \& Social Welfare: Vol. 15 : Iss. 2 , Article 11. Pg. 139-140

${ }^{48}$ Ibid. Pg. 140 


\section{Obstacles related to the fight against THB and the identification of VHT in Albania}

The US Department of State Report highlights some of the issues related to the reactions of the Albanian governments (over the years) to the fight against THB and the identification, protection, and reintegration of VHT. Among this issues can be mentioned:

- $\quad$ Limited understanding of the THB phenomenon by law enforcers. Police officers have a limited knowledge of human trafficking, failing in some cases to identify individuals involved in forced prostitution or as domestic servants.;

- $\quad$ The punishment and imprisonment of VHT for illegal acts committed as a direct result of being subjected to human trafficking;

- $\quad$ The classification of VHT only on the grounds of being adult or child, and not by the purpose of trafficking;

- $\quad$ The confusion between the overlapping elements of prostitution and trafficking;

- Deactivating the mobile identification units (by the government) because foreign donors did not offer any financial support;

- The strategy and action plan 2014-2017 to combat trafficking remained insufficiently funded;

- $\quad$ Numerous transfer and corruption among police officers;

- $\quad$ The threat to victims and their families during court hearings;

- The illegal operation of employment agencies. According to an international organization's report, only 28 of 47 employment agencies operated legally;

- $\quad$ Lack of efforts by the Albanian government to reduce the demand for sexual exploitation;

- Lack of investigation, prosecution or punishment of any officer or state official involved in the crime of trafficking;

- Officials involvement in trafficking crimes. A former member of Parliament has previously been convicted of trafficking-related crimes; and.

- Mismanagement of ministries responsible for trafficking activities, and diversion of funds for trafficking for other purposes by some of them (ministries) ${ }^{49}$

\section{Barriers faced on reintegration process in Albania}

The US Department of State Report in Trafficking in Person 2016 identifies some issues related to the reintegration of VHT in Albania:

- $\quad$ The shelters managed by the NGOs continue to operate under tight financial conditions and rely on external resources for their operational costs;

${ }^{49}$ US Department of State Report. Trafficking in Person. June 2016. 
- $\quad$ The financial mechanisms used to fund these shelters during the year remained complex and tangible by manipulation by local governments;

- $\quad$ The government's funding for three sheltered managed by NGOs was postponed by two months, and a shelter failed to receive food financing. The supply of food of $\mathrm{NGO} /$ shelters offering reintegration services decreased to 1.8 million Albanian Lek (U\$ 14,035), from 3 million Albanian Lek (U\$ 23,392) in 2015;

- $\quad$ NGO-managed shelters allowed adult victims to leave willingly, while the state-run shelters required the victims to get approval from the head of the shelter;

- $\quad$ Only one NGO-run shelter provided specialized services for children, victims of trafficking, under the age of 16;

- Victims may receive compensation from the government or charge their traffickers; three victims applied for compensation, but their case was pending during the reporting period;

- The NGOs reported that the government did not provide sufficient financial support for the implementation of medical, psychological and reintegration services; and

- $\quad$ Psychological, medical, and reintegration services in state-run shelters were inadequate. ${ }^{50}$

- $\quad$ The fears of service providers that they can be identified by traffickers and, consequently, be intimidated or threatened; and

- Delegated Trauma (experienced by someone else). The trauma associated with trafficking can be devastating and enduring as victims suffer psychological and physical abuse at the hands of traffickers. These traumas have a significant impact on the physical and mental well-being of professionals who help and care for victims. These delegated traumas often referred to as fatigue by extreme or secondary traumatic stress, refers to adverse reactions that may occur when professionals repeatedly witness or hear about difficult experiences of trauma, violence, and victim abuse. ${ }^{51}$

\section{Conclusion}

With some around 45.8 million of VHT and a total of profits of US $\$ 150$ billion per year generated by forced labor in private economy, THB is becoming one of the most concerning problems for government around the world.

Due to the global nature of the phenomena, the study of the state role in this phenomena is of an immediate need. The state has an ambiguous nature.

${ }^{50}$ US Department of State. Trafficking in Persons Report, June 2015.

${ }^{51}$ US Department of State. Trafficking in Persons Report, June 2016. Pg. 38 
On one side its engaged in the fight against THB, and on the other side it can sponsor, support or create the incentives for the phenomena to happen.

To understand the state share in THB a definition of state crime is needed. Kramer C. and R. Michailowski described them as "any action that violates public international law, international criminal law, or domestic law when these actions are committed by individuals acting in official or covert capacity as agents of the state pursuant to expressed or implied orders of the state, or resulting from state failure to exercise due diligence over the actions of its agents. 52

According to Watts: 'State crimes include those cases where states have been intentionally involved in policies and crime (murderer), systematic terrorism, intentional dissolution of families (including kidnapping), systematic arrest, threat and surveillance of its citizens. Much of this activity has been the product of formal political processes - some of them altered and secretive, many of them not.' 53

Green and Ward (2000) defined state crime as the area of overlap between two distinct phenomena: (1) violation of human rights and (2) state organizational deviance that would be subject to widespread censure if it were known. 54

The State's responsibility regarding the fight against the phenomenon of THB and the process of reintegration of victims derives from its obligation to guarantee the rights and freedoms of the individual. In this context the "3P" paradigm is an essential framework to combat human trafficking. Also, a "fourth $\mathrm{P}$ "-for partnership_-serves as a complementary means to achieve progress across the 3Ps and ensure all segments of society are enlisted in the fight against modern slavery.

Social work as an academic discipline plays a central role in the process of defining social problems and finding possible solutions to them. Working at different levels (individual, mezzo, and macro) and heterogeneous environments, social workers, are in a favorable position to accomplish this mission. The ecological approach offers a comprehensive theoretical base that social practitioners can draw upon for effective social treatment. It provides strategies that allow the social worker to move from a micro level of intervention to a macro level of social treatment.

\footnotetext{
${ }^{52}$ Kramer C. R and Michalowski J. R. War, Aggression, and State Crime: A Criminological Analysis of the Invasion and Occupation of Iraq. Revised for the British Journal of Criminology, October 2004. Pg. 5

${ }^{53}$ Watts, R, Bessant, J \& Hil, R 2008, International criminology: a critical introduction, Routledge, Abingdon, UK; New York. Pg. 214

${ }^{54}$ Ronald C. Kramer and Raymond J. Michalowski. War, Aggression and State Crime. BRIT. J. Criminol. (2005).Fq. 446-448
} 
The Albanian government shows insufficient efforts to comply with the 3P paradigm. The factors identified as impeding the fight against THB and the reintegration process make the Albanian government liable for its inability to proactively fight the phenomena and reintegrate VHT.

\section{References:}

1. Aronowitz A, Theuermann G. the Tyurykanova E. Analysing the Business Model of Trafficking in Human Beings to Better Prevent Crime. OSCE, May 2010.

2. Cree, E. Viviene., Clapton, G., Smith, M. The State. Policy Press, University of Bristol, 2015. Pg. IX-X.

3. Directorate-General for External Policies of the Union, Addressing Contemporary Forms of Slavery in EU External Policy.

4. Global Report on Trafficking in Persons 2012.

5. Haken, J. Transnational Crime in The Developing World. Global Financial Integrity. February 2011.

6. Kara. S. Columbia University Press. New York. Sex trafficking. Inside the Business of Modern Slavery.

7. Lenja, V. Profili i situatave të viktimave të trafikimit dhe përpjekjet për përfshirje sociale. IOM, Janar 2015.

8. Lyneham, S. Recovery, return and reintegration of Indonesian victims of human trafficking. Trends \& issues in crime and criminal justice no. 483.

9. Michalowski, J, R. What is Crime? Published online: 18 November 2015.

10. Muço, E. (2013). Trafficking in human beings: Paradigms of a successful reintegration into society (Albanian case). European Scientific Journal., 9(4), European scientific journal, 2013, Vol.9(4).

11. Pardeck, John T. (1988) "An Ecological Approach for Social Work Practice," The Journal of Sociology \& Social Welfare: Vol. 15: Iss. 2, Article 11.

12. Prof. Asquith S, Dr. Clark, C. \& Prof. Waterhouse L. The Role of the Social Worker in the 21st Century - A Literature Review. The university of Edinburgh.

13. Profits and poverty: the economics of forced labor. ILO. 2012.

14. Profits and poverty: The economics of forced labor. ILO. 2014

15. Samantha Lyneham ISSN 1836-2206. Canberra: Australian Institute of Criminology, September 2014.

16. Sokoli, L dhe Gëdeshi I. Trafikimi Rasti i Shqipërisë. Instituti i Sociologisë, 2006, Tiranë.

17. United Nations Office on Drugs and Crime. Crime and its Impact on the Balkans and Affected Countries. March 2008. 
18. US Department of State. Trafficking in Persons Report, June 2011.

19. US Department of State. Trafficking in Persons Report, June 2013.

20. US Department of State. Trafficking in Persons Report, June 2015.

21. US Department of State Report. Trafficking in Person. June 2016.

22. Watts, R, Bessant, J \& Hil, R 2008, International criminology: a critical introduction, Routledge, Abingdon, UK; New York.

\section{WEBSITES}

23. http://www.abs.gov.au/ausstats/abs@.nsf/Web+Pages/Population+Cl ock?opendocument

24. Europol Public information. Trafficking in Human Beings in the European

Union

(https://www.europol.europa.eu/sites/default/files/publications/traffic king_in_human_beings_in_the_european_union_2011.pdf)

25. http://www.europarl.europa.eu/RegData/etudes/note/join/2013/43370 3/EXPO-DROI_NT(2013)433703_EN.pdf

26. https://www.globalslaveryindex.org

27. http://www.legislationline.org/documents/id/7645

28. https://socialworklicensemap.com/macro-mezzo-and-micro-socialwork/

29. http://www.state.gov/documents/organization/210737.pdf 